\title{
Fiscal Decentralisation of Services: The Case of the Local Public Sector in European Countries
}

\author{
Martina Halaskova \\ VŠB -Technical University of Ostrava, Faculty of Economics, Ostrava, Czech Republic \\ Renata Halaskova \\ University of Ostrava, Faculty of Education, Ostrava, Czech Republic \\ Beata Gavurova \\ Technical University of Košice, \\ Faculty of Mining, Ecology, Process Control and Geotechnologies, Institute of Earth Resources, \\ Košice, Slovak Republic \\ Matus Kubak \\ Technical University of Košice, Faculty of Economics, Košice, Slovak Republic
}

Received: 6 January 2021. Revision received: 12 March 2021. Accepted: 29 November 2021

\begin{abstract}
Services are a dynamically developing economic sector in all countries. The paper focuses on public services, evaluated from the perspective of fiscal decentralization. It aims to evaluate the level of fiscal decentralization of expenditures in selected categories of public services in European countries. For this purpose, government expenditures by the local government sector are analyzed in the set of the selected 28 European countries in the period 2010-2018. Cluster analysis has been carried out in order to determine four clusters of countries based on their level of decentralization of expenditures on services. The results show differences in the extent of decentralization between the European countries in the provision of specific public services and reflect the form of financing of local public needs. A low level of fiscal decentralization of expenditures on services (public order and safety; housing and community amenities; recreation, culture, and religion) was observed in the majority of the countries. However, the majority of the countries failed to prove a high level of fiscal decentralization of expenditures on services (social protection, health, education) and a medium level of decentralization of expenditures in terms of general public services and services of economic affairs. These findings demonstrate that the degree of decentralization of public services is determined, to a certain degree, determined by country history and its geographical location, as well as by the different roles of sector-specific public policies. The findings can be helpful for creators of local public policies, strategic plans, and financial concepts.
\end{abstract}

Key Words: Service sector, local public sector, public services, fiscal decentralisation, local expenditure, cluster analysis.

JEL Classification: H41, H75, H76, C38

Reference: Halaskova, M., Halaskova, R., Gavurova, B., Kubak, M. (2021). Fiscal Decentralisation of Services: The Case of the Local Public Sector in European Countries. Journal of Tourism and Services, 23(12), 26-43. doi: 10.29036/jots.v12i23.234

\section{Introduction}

The service sector has become the dominant sphere of market economies over the past years. Public services play a significant role in the service sector in a number of developed countries (Stavytskyy 
et al., 2019; Bercu et al., 2020). Research into public services by use of economic, sector and sectorspecific indicators is particularly significant, underscoring their share on the generation of GDP, employment rate and investments (Hašková et al., 2016; Svoboda \& Applová, 2016; Rod \& Rais, 2017; Peterka et al., 2018; Čizo et al., 2020; Horak et al., 2020; Korshenkov \& Ignatyev, 2020; Kwarciński \& Ulman, 2020). Public services can be approached from other perspectives as well. Being the fundamental condition for a functional, sustainable economy, the range and quality of provided services are substantially affected by the form inhabitants' needs are satisfied. Evaluation of the quality of public services is more complex and comprehensive compared to the private sector (Lethbridge \& De la Motte, 2004; Clifton \& Diaz-Fuentes, 2010; Clifton et al., 2016; Hawrysz, 2016; Mura \& Svec, 2018; Gavurova et al., 2020; Marks-Bielska et al., 2020). A significant aspect in procuring and financing public services is fiscal decentralisation. Fiscal decentralisation is the transfer of various forms of fiscal functions of the central government to lower levels of sub-national governments. (Novak et al., 2016; Rousek, 2017) The main purpose lies in strengthening of the role and significance of hierarchically lower levels of governments, in particular local self-government. The key aspect of fiscal decentralisation is to attain higher efficiency, transparency and responsibility in the provision of public services (Kim, 2019; Neubauerova \& Tomcikova, 2019). The role of fiscal decentralisation is to secure adequate income of transfers from the central government to effectively fulfil the original competences of local governments. In addition, the power to adopt decisions about expenditures is essential (Rousek, 2016; Sacchi \& Salotti, 2016).

Decentralisation of expenditure responsibilities (determination of expenditures) is often considered the first pillar of fiscal decentralisation and it stems from normative recommendation for the division of fiscal functions to individual government levels (Kim \& Dougherty, 2018; Porcceli \& Vidoli, 2020). In terms of decentralisation of expenditure responsibilities, the following can be distinguished: a) responsibility for the production (provision) of public assets, b) responsibility for the procurement and administration of the provided services, c) financing of provided services, d) responsibility for the establishment standards, regulations or norms on the procurement of services. According to Jaura (2001; Mareček \& Machová, 2017) public needs in advanced economies are managed in a democratic way at an appropriate level of various formal structures, and various government levels participate in the management.

Research of fiscal decentralisation mainly concentrates on decentralisation of incomes and expenditures. While the most significant form of decentralisation, fiscal decentralisation of expenditures is only sporadically dealt with in the broader context of services. The research subject in this paper is the local public service sector from the viewpoint of fiscal decentralisation. Therefore, this paper varies from other studies that analyse innovativeness (Ključnikov et al., 2021; Civelek, et al., 2021) and marketing activities of firms in service sector of some European countries (Civelek et al., 2020) and the development of local services by local firms and their impact on local economic, social, development of a specific region in Europe (Civelek et al., 2019; Ključnikov et al., 2020a; Ključnikov et al., 2020b). The authors of this paper specifically concentrate on eight areas of public services and on one form of fiscal decentralisation, namely fiscal decentralisation of expenditures on these services. The paper aims to evaluate the level of fiscal decentralisation of expenditures with regard to selected categories of public services in the European countries.

The research questions are verified in terms of a set of the 28 European countries in connection to the goal.

RQ1: Are public services on social protection, health and education associated with a high level of fiscal decentralisation of expenditures?

RQ2: Are general public services and services of economic affairs linked to the medium level of fiscal decentralisation of expenditures? 
RQ3: Is a low level of fiscal decentralisation of expenditures typical of public services of housing and community amenities, services on recreation, culture and religion and services of public order and safety?

\section{Literature review}

Forms of procuring and financing of public services are mainly associated with the position and accountability of the public sector on the national, regional or local levels. As Brown \& Potoski (2003) claim, local and regional governments in EU countries not only make their decisions about the services to be provided or procured, but also about the ways of doing this. In relation to this, current issues are dealt with, as to whether it is more beneficial for the public sector to provide a given public service in terms of its direct field of work, or to delegate the service to another subject (Halaskova \& Halaskova, 2015, p. 599). In particular, services can be procured mainly in two ways: 1) explicitly, for a specific fee, as regular payments from public budgets, or 2) implicitly, by authorising the subject to charge fees to the public (Meričkova et al., 2015; Mikušová Meričková et al., 2017). According to Beblavý \& SičakováBeblavá (2007), the basic decision of local self-governments about the way services will be procured consists in opting for either internalisation of service procurement or externalisation of service provision. Here, fiscal decentralisation plays a significant role in the procurement of public needs (Sumpikova \& Durcekova, 2019; Plaček et al. 2020).

The theory of fiscal federalism and theory of public finances deal with fiscal decentralisation as one of its primary areas. The efficiency of fiscal decentralisation is associated with an efficient form of using financial resources and with purposeful provision of local and regional public services (Kappeler \& Välilä, 2008; Halaskova \& Halaskova, 2016; Bublienė et al., 2019; Kim, 2019). As research shows (Freinkman \& Plekhanov, 2009; Sow \& Razafimahefa, 2015; Meričková et al., 2017; Šuleř \& Machová 2020) this is also connected to an effective division of competences, power and responsibility in decisionmaking about the ensuring of public goods and services, but also with the forms of financing the needs of the public sector between the individual levels of government. There exists a fundamental question of whether public goods and public services should be managed centrally or de-centrally. Some authors (e.g. Rekova et al., 2018; Makreshanska-Mladenovska \& Petrevski, 2019) argue that fiscal operations are not usually implemented at a single government level, but at several government levels (or outside them too). A variety of approaches towards fiscal decentralisation can be found in literature and studies, e.g. the World Bank. Fiscal decentralisation can be performed by transferring competences regarding tax incomes and public expenditures; transferring competences in the area of public expenditures, or an increased participation of lower government levels in decision-making about some public goods (Jankovics, 2016; Onofrei et al. 2020; Slavinskaite et al., 2020). In advanced market economies, a whole range of approaches is applied in measuring fiscal decentralisation (Price \& Garello, 2003; Vo, 2008; Vokoun, 2017; Dias et al., 2020; Jankowiak, 2020). These approaches are associated with the creation of "decentralisation indices" and ways of measuring and evaluating fiscal decentralisation.

Some research deals with public services, their quality and the efficiency of allocated expenditures or provision of public services in relation to fiscal decentralisation (Dillinger, 1994; Azfar et al., 1999; Khaleghain, 2003; Sacchi \& Salotti, 2016; Diaz-Serano \& Meix-Llop, 2019; Kyriacou \& Roca-Sagales, 2019). Azfar et al. (1999) address the issues of fiscal decentralisation and public service provision in particular through a selective review of literature. These authors mainly discuss the impact of institutional measures related to decentralisation. Sow \& Razafimahefa (2015) explore the impact of fiscal decentralisation on the efficiency of public service delivery. Their results show that a sufficient degree of expenditure decentralisation is necessary to obtain favourable outcomes, which need to be accompanied by sufficient decentralisation of revenues. The authors reached the conclusion that fiscal decentralisation can improve the efficiency of public service delivery. Other authors examine the fiscal decentralisation 


\section{JOURNAL OF TOURISM AND SERVICES}

Issue 23, volume 12, ISSN 1804-5650 (Online)

www.jots.cz

of selected services sectors (Zeibote et al., 2019; Mazzanti et al., 2020; Onofrei et al., 2020). Arends (2020) examines the basic rationale behind decentralising public services, in particular two important sectors of services, i.e. health and education. Kyriacou \& Roca-Sagales (2019), evaluate the link between fiscal decentralisation and public service provision based on perception measures of the quality, paying attention to decentralisation measures that disaggregate spending according to expenditure functions in the selected areas of the public sector (education, health and social protection) in European countries.

Kappeler \& Välilä (2008) suggest that fiscal decentralisation boosts economically productive public investments, notably transport and technical infrastructure. At the same time, fiscal decentralisation curbs the relative share of economically less productive investments, such as recreational services. Freinkman \& Plekhanov (2009) analysed the relationship between fiscal decentralisation and the quality of public services of education in Russian regions. According to Dillinger (1994), who focuses on the improvement of the efficiency of urban service delivery in developing countries, failures in urban service delivery are not merely the inadvertent result of problems in the relationship between central and local government. The World Bank (2001) renders another view on decentralisation of services, where indicators of fiscal decentralisation are measured, i.e. financial autonomy of self-governments, the share of expenditures on selected public sector areas from the total amount of expenditures of sub-national levels government (education, health, social protection, public order and safety, housing) as a percentage of total expenditures of sub-national government levels. Also the significance of fiscal sustainability on the level of local and regional governments must be mentioned in relation to fiscal decentralisation and the development of the service sector. According to some authors, e.g. Subires et al. (2019) or Virglerova et al. (2020), financial sustainability is considered an effective means for reduction of local government expenditures.

\section{Methodology}

\subsection{Data}

The paper utilises data from the Eurostat database - Classification of the functions of government. The selected set comprises 28 European countries (27 EU countries and the United Kingdom). The local government sector includes all government units with power and responsibility over small administrative areas (municipalities, villages). For more information, see for instance Lledo et al. (2018). In the present analysis, fiscal decentralisation of expenditures is evaluated by 1) local government expenditures as a percentage of GDP; 2) local government expenditures as percentage of total general government expenditures. In terms of the application to public services, fiscal decentralisation of expenditures is evaluated as the share of local government expenditures by function as a percentage of total local expenditures. The Fiscal decentralisation dataset draws from Government Finance Statistics expenditure data classified by economic function (Classification of the Functions of Government).

As regards the structure of government expenditures (by Classification of the Functions of Government first level), an in-depth analysis is carried out of the following 8 areas: General public services, Public order and safety, Economic affairs, Housing and community amenities, Health, Recreation, culture and religion, Education, Social protection. More detailed descriptions of the services (functions) are provided by Eurostat (2019). The Pearson correlation coefficient was applied to test the relations between the variables (local government expenditure by services (function) as percentage of total local government expenditures) as average in the period 2010-2018. Local government expenditures on defence were not included in the analysis of local government expenditures, as these expenditures are zero in most countries, as well as local government expenditures on environmental protection, which were excluded on account of a high correlation with other local government expenditures (Table 1).

Table 1. Correlation matrix of local government expenditures by function in European countries 
(2010-2018)

\begin{tabular}{|l|c|c|c|c|c|c|c|c|c|}
\hline & GPS & POS & EA & EP & HCA & HE & RCR & EDU & SP \\
\hline GPS & 1 & & & & & & & & \\
\hline POS & .098 & 1 & & & & & & & \\
\hline EA & -.043 & .031 & 1 & & & & & & \\
\hline EP & $.772^{* *}$ & .116 & .196 & 1 & & & & & \\
\hline HCA & .143 & -.189 & -.116 & .178 & 1 & & & & \\
\hline HE & -.355 & $-.383^{*}$ & -.302 & $-.543^{* *}$ & -.360 & 1 & & & \\
\hline RCR & $.423^{*}$ & .024 & .113 & .346 & $.554^{* *}$ & $-.563^{* *}$ & 1 & & \\
\hline EDU & $-.697^{* *}$ & -.082 & .047 & $-.528^{* *}$ & -.084 & .070 & -.133 & 1 & \\
\hline SP & $-.491^{* *}$ & .139 & -.212 & $-.461^{*}$ & -.336 & .119 & $-.497^{* *}$ & -.064 & 1 \\
\hline **. Correlation is significant at the 0.01 level (2-tailed), *. Correlation is significant at the 0.05 level (2-tailed). \\
Note: GPS - General public services, POS - Public order and safety, EA - Economic affairs, EP - Environmental \\
protection, HCA - Housing and community amenities, HE - Health, RCR - Recreation, culture and religion, EDU - \\
Education, SP - Social protection \\
Source: the authors' own contribution based on Eurostat (2020)
\end{tabular}

\subsection{Methods}

The subject of the analysis is fiscal decentralisation of expenditures and public services at the local government level. Fiscal decentralisation of the selected public services in the period 2010-2018 was evaluated by means of cluster analysis. Cluster analysis is a multi-dimensional statistical method used to classify objects. It is used to classify units into groups (clusters) where units in the same group are more similar than units from the other groups. Cluster analysis stems from the similarity (distance) of objects (Roszko-Wójtowicz \& Grzelak, 2021). Various methods are used to measure the distances between points of interval variables (Kovacova et al., 2019). The most used measures are Euclidean distances

$$
\left(d(X, Y)=\sqrt{\sum\left(X_{i}-Y_{i}\right)^{2}}\right)
$$

or of squared Euclidean distances

$$
\left(d(X, Y)=\left(X_{i}-Y_{i}\right)^{2}\right)
$$

Hierarchical clustering offers more alternative solutions, and the outcome of clustering can be expressed by means of a dendrogram (Hennig et al., 2015; Thalassinos et al., 2019). In the present example, the hierarchical cluster analysis applies Ward's method, based on dispersion analysis. It joins clusters with a minimum sum of squares, and the distances are measured by square Euclidean distance (Thalassinos et al., 2019). A cluster can be described largely by the maximum distance needed to connect parts of the cluster. At different distances, different clusters will form, which can be represented using a dendrogram ('hierarchical clustering'). These algorithms do not provide a single partitioning of the data set, but instead provide an extensive hierarchy of clusters that merge with each other at certain distances (Wierzbicka, 2020). In a dendrogram, the y-axis marks the distance at which the clusters merge, while the objects are placed along the $\mathrm{x}$-axis such that the clusters don't mix. Moreover, the box-plot is applied as a way of visualising numerical data using their quartiles (see Mazzocchi, 2008, p. 86). Hierarchical clustering has been applied in the research by Halaskova \& Halaskova (2016) or Gnat (2019). The data were processed using IBM SPSS Statistic 26. 


\section{Results}

In the period 2010-2018 as average, the areas in focus of the 28 European countries are: 1) fiscal decentralisation of expenditures by the local government sector, and 2) fiscal decentralisation of expenditures by the selected public services.

\subsection{Public Expenditures by Local Public Sector in European Countries}

In the present study, the authors pay attention to the analysis of fiscal decentralisation of expenditures at the local government level in European countries, i.e. local government expenditures (as percentage of GDP and as percentage of total government expenditures) in the period 2010-2018 as average (Table 2). Oplotnik \& Finžgar (2013) evaluate countries as those with a high level of fiscal decentralisation (above 30\%), medium level of fiscal decentralisation (between 20-30\%) and low fiscal decentralisation (below 20\%), see also research by Halaskova \& Halaskova (2016). As Table 2 shows, high fiscal decentralisation of expenditures (above 30\%) in the period 2010-2018 is seen in five out of 28 European countries. The highest rate of decentralisation of expenditures at the local level of government is in Denmark (approximately 63\%), Sweden (48\%) or Finland (41\%). These countries manifest a strong autonomy of local budgets and independence on the central government. A medium rate of fiscal decentralisation of expenditures is seen in nine, and a low rate of decentralisation in 13 countries out of 28.

Table 2. Public expenditures by local public sector in the period 2010-2018

\begin{tabular}{|c|c|c|c|c|c|}
\hline \multirow{2}{*}{ Countries } & \multicolumn{2}{|c|}{ Local expenditure } & \multirow{2}{*}{ Countries } & \multicolumn{2}{|c|}{ Local expenditure } \\
\hline & as $\%$ of GDP & as $\%$ of total exp. & & as $\%$ of GDP & as $\%$ of total exp. \\
\hline Belgium & 7.3 & 13.5 & Lithuania & 8.8 & 24.0 \\
\hline Bulgaria & 7.7 & 20.8 & Luxembourg & 4.9 & 11.4 \\
\hline Czechia & 11.4 & 27.1 & Hungary & 8.6 & 17.6 \\
\hline Denmark & 35.1 & 63.8 & Malta & 0.6 & 1.5 \\
\hline Germany & 7.8 & 17.4 & Netherlands & 14.2 & 31.2 \\
\hline Estonia & 9.5 & 24.3 & Austria & 8.4 & 16.4 \\
\hline Ireland & 3.5 & 8.9 & Poland & 13.5 & 31.6 \\
\hline Greece & 3.4 & 6.4 & Portugal & 6.3 & 12.9 \\
\hline Spain & 6.2 & 13.9 & Romania & 9.5 & 26.0 \\
\hline France & 11.5 & 20.2 & Slovenia & 9.2 & 18.6 \\
\hline Croatia & 11.9 & 25.0 & Slovakia & 6.8 & 16.3 \\
\hline Italy & 14.7 & 29.0 & Finland & 23.0 & 41.0 \\
\hline Cyprus & 1.7 & 4.0 & Sweden & 24.4 & 48.8 \\
\hline Latvia & 10.2 & 26.0 & United Kingdom & 11.2 & 25.0 \\
\hline
\end{tabular}

Source: Eurostat (2020); authors' own contribution

The lowest rate of fiscal decentralisation of expenditures is seen in small countries of Malta, Cyprus, or Greece. According to Jaura (2001), the average share of local governments in total expenditures reached $25 \%$, while in countries with an intermediate and local governmental level this share reached up to $41 \%$. Similar results have been obtained by other authors as well, Slavinskaite et al., 2020), who evaluate fiscal decentralisation in European countries, regional disparities or relations of the central and the local government sector.

From the total volume of local government expenditures over the period 2010-2018 in the EU countries, Social protection accounted for the highest share of expenses (around 24\%), followed by 
Education (around 16.5\%), General public services (around 14.6\%), Healthcare (around 14\%), and Economic affairs (around 13\%). The remaining local public services (i.e. Recreation, culture and religion about 5.5\%, Environmental protection about 5\%, Housing and community amenities 4\%, Public order and safety around $3.4 \%$ ) accounted for about $17.5 \%$ of the total local expenditures in the EU.

As regards the services of Social protection, the highest volume of local expenditures (between 30-60\%) was spent in Denmark, Germany, the United Kingdom, and Ireland. The highest volume of local expenditures on Education (between 37-40\%) is observed in Slovakia, Latvia, Estonia, Slovenia, and Lithuania. By contrast, the highest volume of local government expenditures on General public is seen in Malta (53\%) and Cyprus (42\%)- compared to Denmark below 4\%, Ireland (5\%) or Estonia (7\%), the Netherlands (7\%) and the United Kingdom (7\%). The highest volume of local government expenditures on Healthcare is seen in Italy (47\%), Sweden and Finland (27\%) and Denmark, 24\%. (Eurostat, 2020).

\subsection{Public Services and Fiscal Decentralisation of Expenditures in European Countries - Results of Cluster Analysis}

This section presents the results of fiscal decentralisation of expenditures at the local government level in eight categories of public services by applying cluster analysis. WE use Ward's cluster method to obtain balanced clusters in terms of number of countries within every cluster. To standardise variables, we applied range -1 to 1 transformation. Figure 1 depicts phylogenetic tree (dendrogram) of division of 28 European countries into five clusters by internal similarity of the rate of local government expenditures as percentage of total local expenditures in the period 2010-2018.

One can see that we are able to define 4 clusters of countries in relation to the volume of local government expenditures. Most robust is the first cluster of countries, where we rank Belgium Germany, Ireland, Netherlands and United Kingdom. This cluster is formed by relatively homogenous, economically strong countries. Among countries from first cluster we observe quite strong similarities between Germany, Netherlands and United Kingdom. Ireland and Belgium are little bit separate from the rest of the cluster. Second cluster can be also seen as homogenous one, as it is formed solely by former communist countries, namely Bulgaria, Croatia, Czechia, Estonia, Latvia, Lithuania, Poland, Romania, Slovakia and Slovenia. Within second cluster, we observe strongest similarities in terms of the volume of local government expenditures between Czechia, Poland and Romania, then between Estonia, Slovenia and Latvia, to which Bulgaria and Croatia; and Slovakia and Lithuania are also relatively close. Third cluster is formed by economically efficient countries from central-west Europe, namely Austria, Denmark, Finland, Italy and Sweden. The strongest similarities as regards the volume of local government expenditures is seen in Finland, Sweden and Austria. Less seminaries in the evaluated local government expenditures are seen in case of Italy and Denmark. Fourth cluster comprises Cyprus, France, Greece, Hungary, Luxembourg, Malta, Portugal and Spain. Final, fourth cluster is formed mainly by southern European countries and small countries of Europe, which obviously operate in different regimes in terms of volume of local government expenditures. Luxembourg - a country which is often seen as an outlier, as its GDP per capita is one of the highest in the world; and Hungary, which is part of the Visegrad group and which has recently undergone significant reforms and modernisation of public administration, including the implementation of online services. In fourth cluster, we find strongest similarities between Hungary, Portugal, France and Greece. Also, Spain and Luxembourg are quite close to those countries. Malta and particularly Cyprus can be seen as outlying countries within fourth cluster.

More specific information about the clusters by the volume of local government expenditures as $\%$ of total level of decentralisation of expenditures by services is provided in Figure 2 and Table 3. The results of the comparison of fiscal decentralisation of expenditures by public services in 28 European countries show that countries in first, second and third cluster share the lowest rate of decentralisation of general public services. 
A low decentralisation of expenditures is seen in the case of services of public order and safety in all clusters. Economic affairs are relatively faintly decentralised in third cluster. Housing and community amenities are relatively significantly decentralised in fourth cluster. A low level of decentralisation of expenditures on health is seen in countries in first and fourth cluster. On the other hand, health expenditures are decently decentralised in the second cluster, and significantly decentralised in the third cluster. Recreation, culture and religion expenditures are quite markedly decentralised in the fourth cluster (especially Cyprus and Luxembourg), as compared to other clusters. Education expenditures are significantly decentralised in the second cluster (Estonia, Latvia, Lithuania, Slovakia, Slovenia), moderately decentralised in the first cluster and relatively weakly decentralised in the third and fourth clusters. Finally, social protection expenditures are strongly decentralised in the first and third clusters and weakly decentralised in the second and fourth clusters (in the case of Cyprus and Malta, expenditures on social protection are fully centralised).

Figure 1. Phylogenetic tree of local government expenditures by function in European countries (2010-2018)

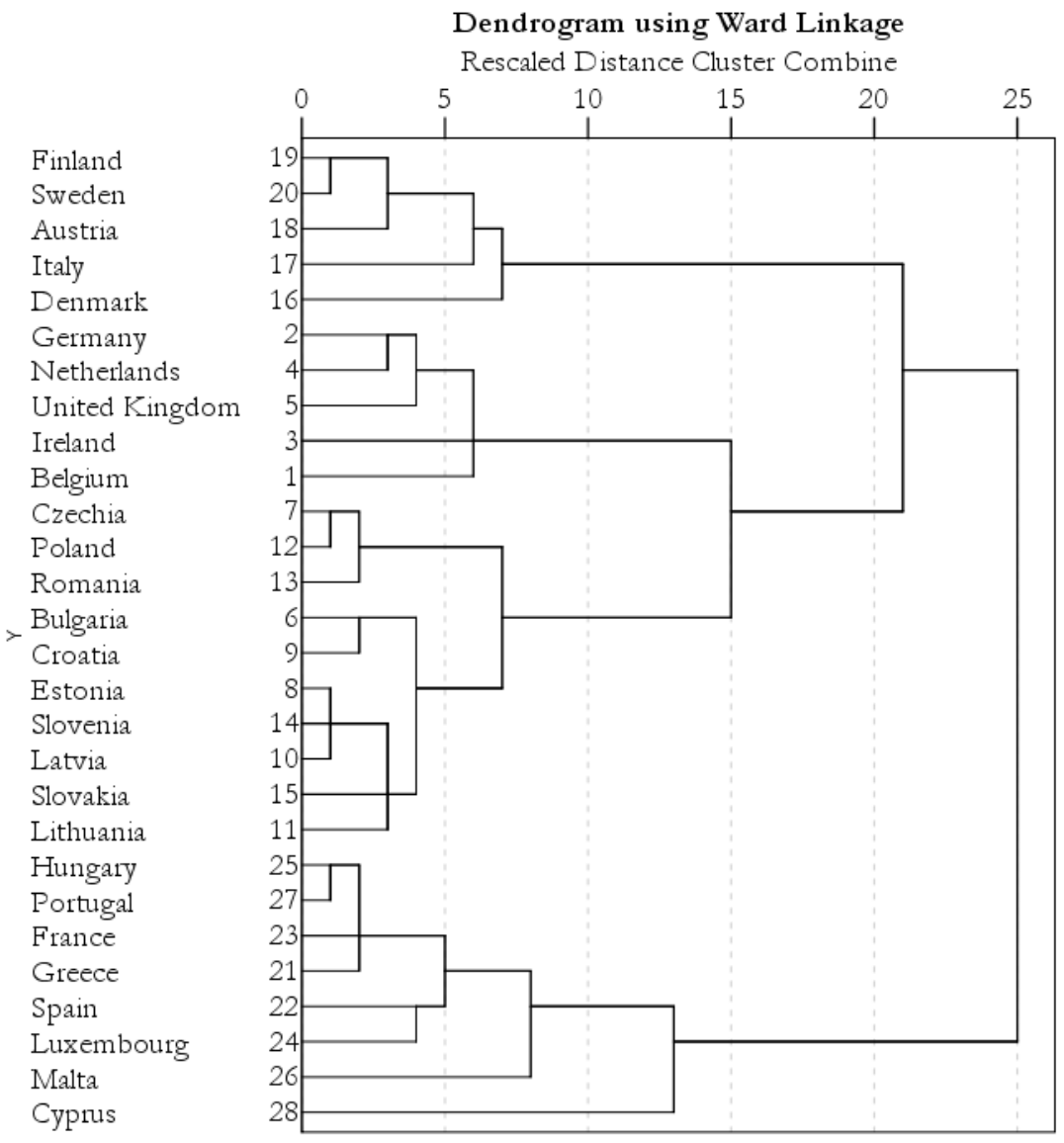

Source: the authors' own contribution based on Eurostat (2020)

When comparing the results with the highest rate of fiscal decentralisation of expenditures by public services by the cluster of countries (Table 3, Figure 2), then the first cluster shows the highest rate of fiscal decentralisation of expenditures on economic affairs, education and social protection. The typical feature of the second cluster of countries is a high rate of decentralisation of expenditures on health, economic affairs and education.

When compared to the other countries, the third cluster shows the highest rate of decentralisation of expenditures on general public services, health, education, and social protection. The fourth cluster demonstrates the outperforming decentralisation public administration (general public services) and 
economic affairs. On the other hand, weakest levels of decentralisation can be found in first cluster as far as housing and community amenities, health and recreation, culture and religion are concerned. Further low level of decentralisation of housing and community amenities and recreation, culture and religion are also found in third cluster. In fourth cluster we can find very low level of decentralisation of health services. Public order and safety is weakly decentralised in all clusters.

Figure 2. Box plot of fiscal decentralisation of expenditures by function in European countries in 20102018 ( $\%$ of total local expenditures)

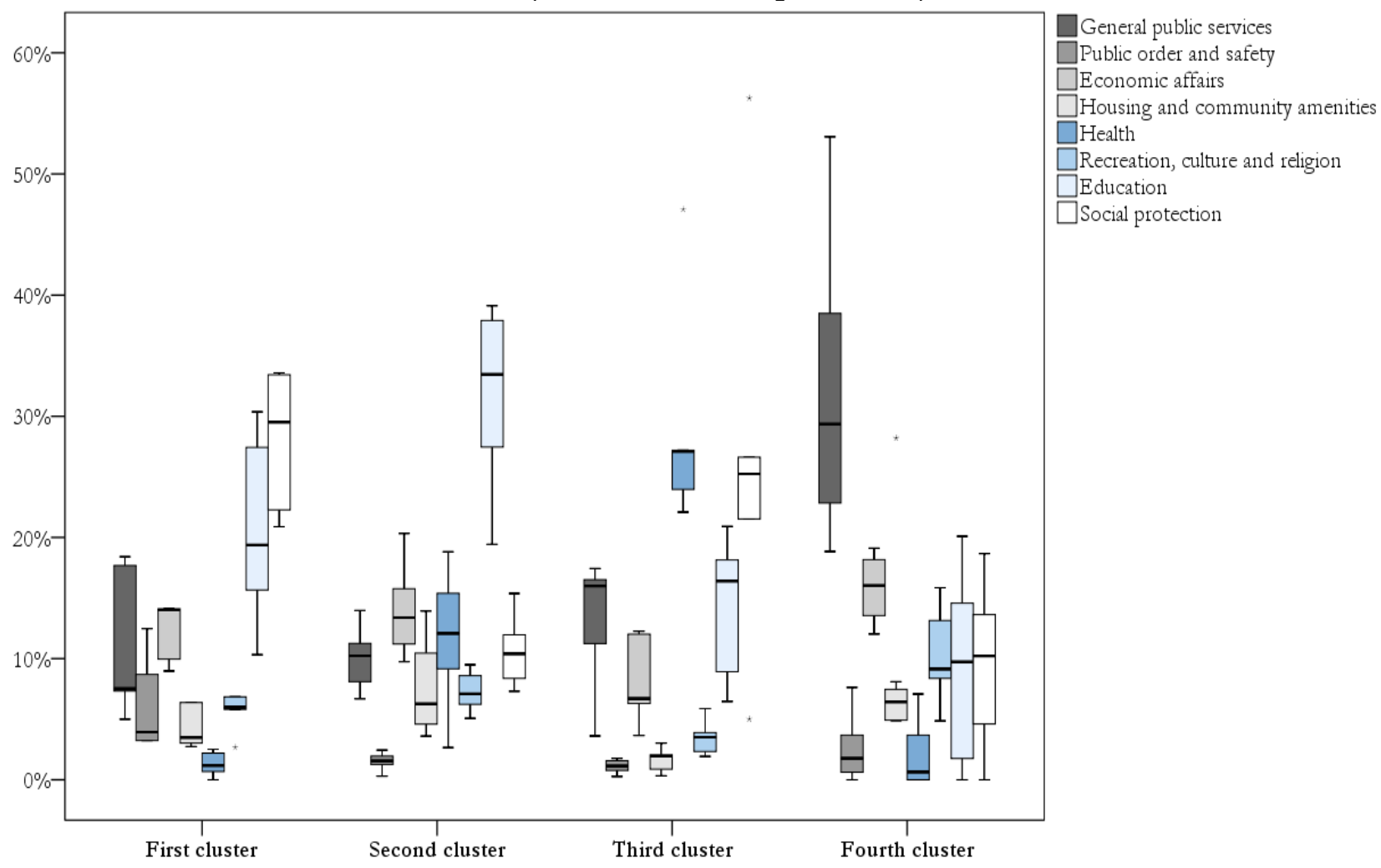

Source: the authors' own contribution based on Eurostat (2020)

Table 3. Clusters of European countries according to fiscal decentralisation of expenditures by public services in $2010-2018$ ( $\%$ of total local expenditures)

\begin{tabular}{|l|c|c|c|c|c|c|c|c|}
\hline \multirow{2}{*}{$\begin{array}{l}\text { FD expenditures by public } \\
\text { services }\end{array}$} & \multicolumn{2}{|c|}{ First cluster } & \multicolumn{2}{c|}{ Second cluster } & \multicolumn{2}{c|}{ Third cluster } & \multicolumn{2}{c|}{ Fourth cluster } \\
\cline { 2 - 10 } & Mean & Median & Mean & Median & Mean & Median & Mean & Median \\
\hline General public services & 11.19 & 7.53 & 10.03 & 10.23 & 12.96 & 15.99 & 31.67 & 29.36 \\
\hline Public order and safety & 6.32 & 3.93 & 1.56 & 1.56 & 1.10 & 1.13 & 2.47 & 1.77 \\
\hline Economic affairs & 13.64 & 14.01 & 14.04 & 13.38 & 8.19 & 6.70 & 14.33 & 16.03 \\
\hline Housing and community & 6.06 & 3.49 & 7.58 & 6.27 & 1.65 & 1.96 & 8.23 & 6.42 \\
\hline Health & 1.32 & 1.18 & 12.02 & 12.08 & 29.49 & 27.11 & 1.96 & .64 \\
\hline Recreation, culture and religion & 6.14 & 5.98 & 7.38 & 7.10 & 3.51 & 3.51 & 10.26 & 9.15 \\
\hline Education & 20.64 & 19.38 & 32.07 & 33.46 & 14.17 & 16.40 & 9.03 & 9.73 \\
\hline Social protection & 27.94 & 29.52 & 10.53 & 10.40 & 26.94 & 25.24 & 9.45 & 10.22 \\
\hline
\end{tabular}

Source: the authors' own contribution based on Eurostat (2020) 


\section{JOURNAL OF TOURISM AND SERVICES}

Issue 23, volume 12, ISSN 1804-5650 (Online)

www.jots.cz

When the present results of the level of fiscal decentralisation of expenditures are applied to public services (according to Oplotnik \& Finžgar, 2013), it can be said that a high level of fiscal decentralisation of expenditures (above 30\%) at the local level of government is reached only in general public services in the countries of the fourth cluster, services of health in the countries of the third cluster, and services of education in the countries of the second cluster. Medium level of fiscal decentralisation by services (between 20-30\%) was found in social protection in the countries of the third cluster and in education and social protection in the countries of the first cluster. With respect to the specific structure of expenditure competences (function) of the local government levels in the individual countries, $20 \%$ and more can be considered a high level of fiscal decentralisation, 10-20\% a medium level of fiscal decentralisation, and below $10 \%$ a low level of fiscal decentralisation. The number of countries by fiscal decentralisation of expenditures by public services in the period 2010-2018 is listed in Table 4.

Table 4. Number of European Countries according to fiscal decentralisation of expenditures by public services

\begin{tabular}{|l|c|c|c|c|c|c|c|c|}
\hline \multirow{2}{*}{$\begin{array}{l}\text { Level of FD } \\
\text { exp. }\end{array}$} & $\begin{array}{c}\text { General } \\
\text { public } \\
\text { services }\end{array}$ & $\begin{array}{c}\text { Public } \\
\text { order and } \\
\text { safety }\end{array}$ & $\begin{array}{c}\text { Economic } \\
\text { affairs }\end{array}$ & $\begin{array}{c}\text { Housing } \\
\text { and } \\
\text { community } \\
\text { amenities }\end{array}$ & Health & $\begin{array}{c}\text { Recreation, } \\
\text { culture and } \\
\text { religion }\end{array}$ & Education & $\begin{array}{c}\text { Social } \\
\text { protection }\end{array}$ \\
\hline $\begin{array}{l}\text { FD exp. 20\% } \\
\text { and above }\end{array}$ & 7 & 0 & 2 & 1 & 5 & 0 & 13 & 9 \\
\hline $\begin{array}{l}\text { FD exp. 10- } \\
20 \%\end{array}$ & 13 & 1 & 19 & 4 & 7 & 3 & 9 & 10 \\
\hline $\begin{array}{l}\text { FD exp. 10\% } \\
\text { and less }\end{array}$ & 8 & 27 & 7 & 23 & 16 & 25 & 6 & 9 \\
\hline
\end{tabular}

European countries show differences in the rate of decentralisation in the provision of particular public services. This fact is related to the specific features of local administrative structures and a different scope of expenditure competences of the individual administrative levels (regional or local government) in the countries, but also to the role public policies play.

Resources must be used economically and efficiently in order to reach an appropriate level of the provided public services. A number of countries define a minimum standard of public services on the part of the government, in order to avoid uneconomical allocation of financial resources to infrequently used services provided locally. These countries thus have the option to check the extent and quality of public services provided in the decentralised manner (Hawrysz, 2016).

\section{Discussion}

Three research questions related to the evaluation of fiscal decentralisation of expenditures on public services in 28 European countries have been posed. As regards the verification of the research question RQ1: "Are public services on social protection, bealth and education connected with a bigh level of fiscal decentralisation of expenditures?", it can be said that a high level of decentralisation of expenditures on services related to social protection is observed in the countries in the first and third clusters. A high decentralisation of health services is typical of the countries in the third cluster, and a high decentralisation of expenditures on education of countries in the first and second cluster. A high level of decentralisation of expenditures on the local level can be seen in services (social protection in nine countries, education in 13 countries, health in five countries). Based on the results (Table 4) it can be said that a high rate of decentralisation of expenditures on social protection, health and education has been confirmed only in less than a half of the examined countries, hence the answer to RQ1 is negative (NO). 


\section{JOURNAL OF TOURISM AND SERVICES}

Issue 23, volume 12, ISSN 1804-5650 (Online)

www.jots.cz

The second research question (RQ2) verified whether: "general public services and services of economic affairs are linked to the medium level of fiscal decentralisation of expenditures?" A medium level of fiscal decentralisation of expenditures on general public services are seen in the countries in the first cluster (BE, GE) and selected countries in the second and third clusters. In the case of economic affairs, the medium level of decentralisation is linked to selected countries in the first and second clusters and countries in the fourth cluster (with the exception of CY). The results (Table 4) clearly show that the medium level of decentralisation of expenditures is reached in general public services (13 countries from 28 ) and in the economic affairs (19 countries out of 28). A medium level of decentralisation in public services - economic affairs - has been proven in the majority of countries, whereas in general public services only in less than a half of the analysed countries. Therefore, the answer to research question RQ2 is negative $(\mathrm{NO})$.

In terms of the third research question (RQ3) the following question has been verified: "Is the low level of fiscal decentralisation of expenditures typical of public the public services on housing and community amenities, services on recreation, culture and religion and services of public order and safety?" Based on the results of the local level, it can be said that the majority of the analysed countries reach a low level of decentralisation of expenditures on public order and safety ( 27 countries), on housing and community amenities ( 23 countries), and recreation, culture and religion (25 countries). On the basis of these findings (Table 4), a low level of fiscal decentralisation of expenditures has been confirmed in the majority of the analysed countries. Therefore, the answer to RQ3 is positive (YES).

Similarly to the present research, other authors take a similar stance towards the issue in question. According to NALAS Report (2018, p. 6-8), there is "an inverse relationship between the level of decentralisation measured by the scope of the social functions devolved to the local governments and the size of the public sector. The functional allocation of expenditures shows that SEE local governments spend most of their budgets on Education and Housing and Community Amenities: Education takes 40$60 \%$ of municipal budgets such as Slovenia and Bulgaria - which is 2-3 times more than the EU28 average. In Albania or Croatia, local governments spend one quarter to one third of all expenditures on services of housing and community amenities, but services of environmental protection is where almost all SEE countries spend the least".

According to Jaura (2001); Oplotnik \& Finžgar (2013); Sow \& Razafimahefa (2015); Neubauerova \& Tomcikova (2019), experience of the countries shows that fiscal decentralisation should pertain to all government levels (central, state, local). "The crucial question in many countries is whether the central government should devise a system of fiscal decentralisation that should cover all government levels, or whether each state/province/ region should devise its own internal system" (Halaskova \& Halaskova, 2016, p. 381).

Arends (2020, p. 599) argues that, "there is evidence supporting both the decentralisation-enthusiastic and the decentralisation-skeptical views. Author also state that when decentralising public services, reformers should be knowledgeable about the specificities of the public service, the local context, and the effects of the design of fiscal relations". According to Azfar et al. (1999), the overall impact of decentralisation on service delivery depends critically on its design and prevailing institutional arrangements. Sanogo (2019, p. 204) finds that "increased local revenue positively affects access to public services and reduces poverty and states that there is evidence that revenue decentralisation has a more robust effect on access to public service, than on poverty, mainly through enhancing access to education more than access to health, water, and sanitation services". Some authors also discuss a number of current issues related to fiscal decentralisation of public services, in particular their quality and efficiency. The evaluated areas in focus are mainly the positive and negative impact of fiscal decentralisation on selected public services. He et al. (2020) found out that financial decentralisation has an impact on public infrastructure and services through government financial resources. Conversely, fiscal and financial decentralisations have an indirect impact on the infrastructure construction in the adjacent areas. Robinson (2007, p.1) shows that there is no systematic or comparative evidence on whether increased participation in decentralised local governance generates better output. He proves the results by showing improvements in the provision of health, education and other services. The positive impact of fiscal decentralisation on the quality of public service delivery in the area on 
education is indicated by Diaz-Serano \& Meix-Llop (2019). Freinkman \& Plekhanov (2009) have concluded that fiscal decentralisation has no significant effect on the key inputs into secondary education, but has a positive impact on the quality of municipal utilities provision. Other authors e.g. Letelier-S. \& Sáez-Lozano (2020), found that fiscal decentralisation in education and housing have a negative effect on well-being, but this effect is positive in the cases of health, culture and recreation.

In terms of the socio-economic development, it is crucial for local governments in the EU countries to procure local public services for the citizens (social services, health care, pre-primary and primary education, public transport, etc.). One of the main priorities related to the COVID-19 pandemic is to procure local services in social protection and healthcare, including the provision of the staff and financing. Moreover, local governments might stimulate entrepreneurial attitudes of women to decrease gender inequalities (Ključnikov et al., 2019).

In connection with the findings, the topic for further research can be the evaluation of the main areas of the public sector (health care, social protection) on not only the regional, but also the national level, with focus on quality and efficiency of public services.

\section{Conclusion}

The paper aimed to evaluate the level of fiscal decentralisation of expenditures for selected categories of public services for a set of 28 European countries. In the period 2010-2018 the results of cluster analysis showed a division of the countries by fiscal decentralisation of expenditures on service at the local level into four clusters based on their internal similarity. The results have confirmed a low level of fiscal decentralisation of expenditures on services (public order and safety; housing and community amenities, recreation, culture and religion) in the majority of countries. However, neither a high level of fiscal decentralisation of expenditures on services (social protection, health, education), nor a medium level of decentralisation of expenditures in terms of general public services and services of economic affairs have been proven in the majority of the evaluated countries. Differences in expenditure competences of local and sub-national governments and the rate of decentralisation of services of the local public sector are associated with the specific arrangement of countries, where each country creates its own system of the arrangement of local relationships, which lead to changes on the sub-national government level. The findings demonstrate a different approach in terms of priorities of local governments and public policies in securing and financing public services as well as extremes in fiscal decentralisation of expenditures by public services.

\section{Acknowledgments:}

This research was supported by the Scientific Grant Agency of the Ministry of Education, Science, Research, and Sport of the Slovak Republic and the Slovak Academy Sciences as part of the research project VEGA 1/0797/20: "Quantification of Environmental Burden Impacts of the Slovak Regions on Health, Social and Economic System of the Slovak Republic" and within SGS project SP2021/51: "Complex Use of Quantitative Methods in Economic Disciplines" and project VEGA 1/0683/21: "Generation Gap and Provision of Public Services and Administration".

\section{References}

1. Arends, H. (2020). The Dangers of Fiscal Decentralization and Public Service Delivery: a Review of Arguments. Polit Vierteljabresschr 61, 599-622. doi: https://doi.org/10.1007/s11615-02000233-7.

2. Azfar, O., Kahkonen, S. Lanyi, A. \& Meagher, P. (1999). Decentralisation, governance and public services: The impact of institutional arrangements: A Review of the Literature. IRIS Center. 


\section{JOURNAL OF TOURISM AND SERVICES}

Issue 23, volume 12, ISSN 1804-5650 (Online) www.jots.cz

Retrieved December 11, 2020, from http://siteresources.worldbank.org/INTINDONESIA/Resources/Decentralization/Lit_Revie w_IRIS.pdf.

3. Beblavý, M. \& Sičaková-Beblavá, E. (2007). Faktory ovplyvňujúce rozhodovanie o sposobe zabezpečovania služeb vo velkých slovenských mestách. Politická ekonomie, 55(2), 245-262.

4. Bercu, A-M., Tofan, M., Roman, A. \& Vatamanu, A-F. (2020). Public sector performance in EU countries. Key features and perspectives. Transformations in Business \& Economics, 19(2B(50B)).

5. Brown, T. L. \& Potoski, M. (2003). Transaction Costs and Institutional Explanations for Government Service Production Decisions. Journal of Public Administration Research and Theory, 13 (4), 441-468. doi: 10.1093/jpart/mug030.

6. Bublienė, R., Vinogradova, I., Tvaronavičienè, M. \& Monni, S. (2019). Legal form determination for the development of clusters' activities. Insights into Regional Development, 1(3), 244-258. https://doi.org/10.9770/ird.2019.1.3(5)

7. Civelek, M., Ključnikov, A., Krajčík, V., \& Žufan, J. (2019). The Importance of Discount Rate and Trustfulness of A Local Currency for the Development of Local Tourism: Journal of Tourism and Services, 10 (19): 77-92. https://doi. org/10.29036/jots. v10i19. 117.

8. Civelek, M., Gajdka, K., Světlík, J., \& Vavrečka, V. (2020). Differences in the usage of online marketing and social media tools: evidence from Czech, Slovakian and Hungarian SMEs. Equilibrium. Quarterly Journal of Economics and Economic Policy, 15(3), 537-563. doi: 10.24136/eq.2020.024

9. Civelek, M., Ključnikov, A., Fialova, V., Folvarčná, A., \& Stoch, M. (2021). How innovativeness of family-owned SMEs differ depending on their characteristics? Equilibrium. Quarterly Journal of Economics and Economic Policy, 16(2), 413-428. doi: 10.24136/eq.2021.015

10. Clifton, J., Díaz-Fuentes, D. \& Fernández-Gutiérrez, M. (2016). Public Infrastructure Services in the European Union: Challenges for Territorial Cohesion. Regional Studies, 50(2), 358-373. doi: http://dx.doi.org/10.1080/00343404.2015.1044958

11. Clifton, J. \& Díaz-Fuentes, D. (2010). Evaluating EU policies on public services: A citizens' perspective. Annals of Public and Cooperative Economics, 81(2), 281-311. doi: http://dx.doi.org/10.1111/j.1467-8292.2010.00412.x

12. Čizo, E., Ignatjeva, S. \& Lavrinenko, O. (2020). Determinants of financial development of the EU countries in the period 1995-2017. Insights into Regional Development, 2(2), 505-522. doi: https://doi.org/10.9770/IRD.2020.2.2(1).

13. Dias, R., Pardal, P., Teixeira, N. \& Machová, V. (2020). Financial Market Integration of ASEAN5 with China. Literra Scripta, 13(1), 46-63.

14. Diaz-Serano, L. \& Meix-Llop, E. (2019). Decentralization and the quality of public services: Cross-country evidence from educational data. Environment and Planning C: Politics and Space, 37(7), 1296-1316. doi: http://dx.doi.org/10.1177/2399654418824602

15. Dillinger, W. (1994). Decentralization and its implications for urban service delivery. Urban Management and Municipal Finance Discussion Paper No. 16. Retrieved November 25, 2020, from http://documents.worldbank.org/curated/en/952971468739134548/Decentralization-and-itsimplications-for-urban-service-delivery.

16. Eurostat (2020). General government expenditure by function (COFOG). Retrieved December 1, 2020, from http://appsso.eurostat.ec.europa.eu/nui/show.do?dataset=gov_10a_exp\&lang=en.

17. Eurostat (2019). Manual on sources and methods for the compilation of COFOG statistics Classification of the Functions of Government (COFOG). Publications Office of the European Union: Luxembourg. 


\section{JOURNAL OF TOURISM AND SERVICES}

Issue 23, volume 12, ISSN 1804-5650 (Online)

www.jots.cz

18. Freinkman, L. \& Plekhanov, A. (2009). Fiscal decentralisation and the quality of public services in Russian regions. Working Paper No. 111. Retrieved November 15, 2020, from https://www.ebrd.com/downloads/research/economics/workingpapers/wp0111.pdf.

19. Gavurova, B., Ivankova, V., Rigelsky, M. \& Přívarová, M. (2020). Relations Between Tourism Spending and Global Competitiveness - an Empirical Study in Developed OECD Countries. Journal of Tourism and Services, 21(11), 38-54. doi: 10.29036/jots.v11i21.175

20. Gnat, S. (2019). Spatial weight matrix impact on real estate hierarchical clustering in the process of mass valuation. Oeconomia Copernicana, 10(1), 131-151. https://doi.org/10.24136/oc.2019.007

21. Halaskova, M. \& Halaskova, R. (2016). Assessment of Financial Capabilities of Local Governments in EU Countries for the Development of Local Public Services. Lex localis Journal of Local Self-Government, 14(3), 379-397. doi: 10.4335/14.3.379-397(2016).

22. Halaskova, M. \& Halaskova, R. (2015). Fiscal Decentralisation and Provision of Local Public Services in Selected EU Countries, Lex localis-Journal of Local Self-Government, 13(3), 595-613. doi: http://dx.doi.org/10.4335/13.3.595-613(2015).

23. Hašková, S., Babulak, E. \& Vochozka, M. (2016). Intellectual Capital Optimisation in Microeconomic Sphere. Proceedings of the 8th European Conference on Intellectual Capital. Reading, UK: Academic Conferences and Publishing International Limited, pp.112-118.

24. Hawrysz, L. (2016). Quality Measurement in Public Sector Organisations. British Journal of Economics, Management \& Trade, 11(1), 1-7. doi: http://dx.doi.org/10.9734/BJEMT/2016/21973

25. He, J., Zhang, Y. \& Bi, G. (2020). Fiscal decentralization, financial decentralization and public infrastructure. Xitong Gongcheng Lilun yu Shijian/System Engineering Theory and Practice, 40(4), 852 862. doi: 10.12011/1000-6788-2019-0551-11.

26. Hennig, Ch., Meila, M., Murtagh, F. \& Rocci, R. (2015). Handbook of Cluster Analysis. London, New York, NY: CRC Press.

27. Horák, J., Brabenec, T., Hejda, J. \& Mareček, J. (2020). The sharing economy development analysis in the Czech Republic and other selected countries. AD ALTA - Journal of Interdisciplinary Research, 10(1), 109-114.

28. Jankovics, L. (2016). Local Government Finances in Hungary: From the culprit of fiscal slippages to a source of stability? Society and Economy, 38(4), 455-478. doi: http://dx.doi.org/10.1556/204.2016.38.4.2

29. Jankowiak, A. H. (2020). Differentiation of Cluster Policy Instruments in Individual Phases of the Cluster Life Cycle. Transformations in Business \& Economics, 19(2A(50A)).

30. Jaura, Z. (2001). The participation of certain government levels at public expenditures in selected countries. Ekonomicky Casopis, 49(1), 54-87.

31. Kappeler, A. \& Välilä, T. (2008). Fiscal federalism and the composition of public investment in Europe. European Journal of Political Economy, 24(3), 562-570. doi: 10.1016/j.ejpoleco.2008.06.002

32. Khaleghain, P. (2003). Decentralization and public services: the case of immunization. Policy Research Working Paper No. 2989. Retrieved November 25, 2020, from http://documents.worldbank.org/curated/en/596071468766491064/Decentralization-andpublic-services-the-case-of-immunization.

33. Kim, J. \& Dougherty, S. (2018). Fiscal Decentralisation and Inclusive Growth. OECD Fiscal Federalism Studies. Retrieved December 4, 2020, from http://www.oecd.org/tax/federalism/fiscal-decentralisation-and-inclusive-growth.pdf

34. Kim, Y. (2019). Limits of fiscal federalism: How narratives of local government inefficiency facilitate scalar dumping in New York State. Environment and Planning A: Economy and Space, 51(3), 636-653. doi: https://doi.org/10.1177/0308518X18796511

35. Ključnikov, A., Civelek, M., Cech, P. \& Kloudová, J. (2019). Entrepreneurial orientation of SMEs' executives in the comparative perspective for Czechia and Turkey. Oeconomia Copernicana, 10(4), 773-795. doi: 10.24136/oc.2019.035 


\section{JOURNAL OF TOURISM AND SERVICES}

Issue 23, volume 12, ISSN 1804-5650 (Online)

www.jots.cz

36. Ključnikov, A., Civelek, M., Polách, J., Mikoláš, Z., \& Banot, M. (2020a). How do security and benefits instill trustworthiness of a digital local currency? Oeconomia Copernicana, 11(3), 433-465. doi: $10.24136 /$ oc. 2020.018

37. Ključnikov, A., Civelek, M., Vozňáková, I., \& Krajčík, V. (2020b). Can discounts ex pand local and digital currency awareness of individuals depending on their characteristics? Oeconomia Copernicana, 11(2), 239-266. doi: 10.24136/oc.2020.010

38. Ključnikov, A., Civelek, M., Fialova, V., \& Folvarčná, A. (2021). Organizational, local, and global innovativeness of family-owned SMEs depending on firm-individual level characteris tics: evidence from the Czech Republic. Equilibrium. Quarterly Journal of Economics and Economic Policy, 16(1), 169-184. doi: 10.24136/eq.2021.006

39. Korshenkov, E. \& Ignatyev, S. (2020). Empirical interpretation and measurement of the productivity and efficiency of regions: The case of Latvia. Insights into Regional Development, 2(2), 549-561. https://doi.org/10.9770/IRD.2020.2.2(4)

40. Kovacova, M., Kliestik, T., Valaskova, K., Durana, P. \& Juhaszova, Z. (2019). Systematic review of variables applied in bankruptcy prediction models of Visegrad group countries. Oeconomia Copernicana, 10(4), 743-772. https://doi.org/10.24136/oc.2019.034.

41. Kwarciński, T., \& Ulman, P. (2020). Quality of life paradox. Well-being ranking of the selected European countries based on hybrid well-being approach. Economics and Sociology, 13(2), 160-180. doi:10.14254/2071-789X.2020/13-2/12

42. Kyriacou, A. P. \& Roca-Sagales, O. (2019). Local Decentralization and the Quality of Public Services in Europe. Social Indicators Research, 145(2), 755-776. doi: 10.1007/s11205-019-02113.

43. Letelier-S, L. E. \& Sáez-Lozano, J.L. (2020). Expenditure decentralization: Does it make us happier? An empirical analysis using a panel of countries. Sustainability, 12(18), 1-17, 7236. doi: $10.3390 /$ su12187236.

44. Lethbridge, J. \& De la Motte, R. (2004). Public Services in Europe: Trends and Developments - Ten years of EPSU commissioned research from PSIRU: overview and selected works, 1994 - 2004. Retrieved November 5, 2020, from https://www.epsu.org/sites/default/files/article/files/2nd_EPSUPSIRU_Selected_Works_23-5-04.pdf.

45. Liu, L., Kang, C., Yin, Z. \& Liu, Z. (2019). The effects of fiscal and taxation policies on the innovation efficiency of manufacturing enterprises: a comparative study from the perspective of economic regions. Transformations in Business \& Economics, 18(3(48)).

46. Lledo, V. et al. (2018). The IMF Fiscal Decentralization Dataset: A Primer. Washington, DC: International Monetary Fund.

47. Makreshanska-Mladenovska, S. \& Petrevski, G. (2019). Fiscal Decentralisation and Government Size: Evidence from a Panel of European Countries. Hacienda Publica Espanola-Review of Public Economics, 229(2) 33-58. doi: http://dx.doi.org/10.7866/hpe-rpe.19.2.2

48. Mareček, J. \& Machová, V. (2017). The influence of public debt on the performance of the economy. SHS Web of Conferences - Innovative Economic Symposium 2017: Strategic Partnership in International Trade. Les Ulis, France: EDP Sciences.

49. Marks-Bielska, R., Lizińska, W., Wojarska, M. \& Babuchowska, K. (2020). Institutional efficiency versus stability of local governments in basic areas of activity: the case of Poland. Equilibrium. Quarterly Journal of Economics and Economic Policy, 15(3), 463-487. https://doi.org/10.24136/eq.2020.021.

50. Mazzocchi, M. (2008). Statistics for marketing and consumer research. London: Sage.

51. Mazzanti, M., Mazzarano, M., Pronti, A. \& Quatrosi, M. (2020). Fiscal policies, public investments and wellbeing: mapping the evolution of the EU. Insights into Regional Development, 2(4), 725-749. http://doi.org/10.9770/IRD.2020.2.4(1) 


\section{JOURNAL OF TOURISM AND SERVICES}

Issue 23, volume 12, ISSN 1804-5650 (Online)

www.jots.cz

52. Meričková, B.M., Nemec, J., Svidroňová, M.M. \& Pischko, V. (2017). Analysis of the relationship between the size and structure of public expenditure and socio-economic development. Ekonomický ćasopis, 65 (4), 320-333.

53. Merickova, B. M., Nemec, J. \& Svidronova, M. (2015). Co-creation in Local Public Services Delivery Innovation: Slovak Experience. Lex Localis-Journal of Local Self-Government, 13(3), 521 535. doi: 10.4335/13.3.521-535(2015).

54. Mikušová Meričková, B., Nemec J. \& Vozárová, Z. (2017). The efficiency of contracting out local public services in Czech Republic and Slovakia. In Improving public services: international experiences in using evaluation tools to measure program performance. Oxford: Oxford University Press, pp. 265-285.

55. Mura, L. \& Svec, M. (2018). Human Resources in Public and Private Sector: A Comparative Study of Slovakia. Rielik 2017: Reproduction of Human Capital - Mutual Links and Connections. In 10th International Scientific Conference on Reproduction of Human Capital - Mutual Links and Connections (RELIK), Prague, 327-336.

56. NALAS Report (2018). 2018 NALAS’ Fiscal Decentralisation Report: Local services are exacerbated by the deterioration of local finance arrangements. Fiscal Decentralisation Indicators for South-East Europe: 2006-2017. Retrieved November 15, 2020, from http://www.nalas.eu/News/FD_2018.

57. Neubauerova, E. \& Tomcikova, M. (2019). Selected Practical Aspects of the Fiscal Decentralization in the Slovak Republic. Proceedings of the 13th International Scientific Conference Public Economics and Administration 2019. Ostrava: Technical University of Ostrava (pp. 305-315).

58. Novák, V., Vokoun, M., Stellner, F. \& Vochozka, M. (2016). Institutional Analysis of the Contemporary Regional Labour Market in the Czech Republic. E+M Ekonomie a Management, 19(3), 4-15. doi: 10.15240/tul/001/2016-3-001.

59. Onofrei, M., Paraschiv, G., Cigu, E., Vintila, G. \& Gherghina, S.C. (2020). Does fiscal decentralization influence economic growth? Empirical evidence from CEE countries. Transformations in Business \& Economics, 19(2B(50B)).

60. Oplotnik, Z. J. \& Finžgar, M. (2013). EU Member States and Fiscal Decentralization: Empirical Comparison. Innovative Issues and Approaches in Social Sciences, 6(3), 39-64. doi: http://dx.doi.org/10.12959/issn.1855-0541.IIASS-2013-no3-art03

61. Peterka, P., Soběhart, R. \& Jílková, J. (2018). Sharing Economy - a Challenge of the 21st Century?. Littera Scripta, 11(1), 155-169.

62. Plaček M., Nemec J., Ochrana F., Schmidt M. \& Půček M. (2020). Analysis of Factors of Overpricing in Public Procurement: A Study for Low-Performing EU Countries. Global Encyclopedia of Public Administration, Public Policy, and Governance. Cham: Springer

63. Porcceli, F. \& Vidoli, F. (2020). A comprehensive model for the evaluation of standard expenditure needs and standard level of local services. Local Government Studies, 46(5), 734-762. doi: https://doi.org/10.1080/03003930.2019.1682558

64. Roszko-Wójtowicz, E. \& Grzelak, M. M. (2021). Multi-dimensional analysis of regional investment attractiveness in Poland. Equilibrium. Quarterly Journal of Economics and Economic Policy, 16(1), 103-138. https://doi.org/10.24136/eq.2021.004.

65. Price, V. C. \& Garello, J. (2003). Index of Fiscal Decentralisation: Methodology and Findings. Journal des Economistes et des Etudes Humaines, 13(4), 1-40.

66. Rekova, N., Dolozina, I., Nitsenko, V. Zaitsev, Y. \& Zamlynskyi, V. (2018). Budgetary revenue structure at central level of public administration in the federal countries. Administratie si Management Public, (30), 37-50. doi: http://dx.doi.org/10.24818/amp/2018.30-03

67. Robinson, M. (2007). Does Decentralisation Improve Equity and Efficiency in Public Service Delivery Provision? IDS Bulletin, 38(1), 1-11. http://dx.doi.org/10.1111/j.17595436.2007.tb00333.x 


\section{JOURNAL OF TOURISM AND SERVICES}

Issue 23, volume 12, ISSN 1804-5650 (Online) www.jots.cz

68. Rod, A. \& Rais, J. (2017). Analysis of Income and Profitability Indicators in Banking Sectors During the Period 1995 - 2009: Post-communist vs. OECD Countries. Littera Scripta, 10(1), 102116.

69. Rousek, P. (2016). Brief report on public spending on inland and maritime waterways in particular country in certain period of time. Nase More, 63(3), 177-181. doi: 10.17818/NM/2016/SI18.

70. Rousek, P. (2017). Critical Evaluation of Czech Municipal Spending Predictive Models. Innovation Management, Entrepreneurship and Sustainability 2017- Proceedings of the 5th International Conference. Prague: University of Economics, 871-882.

71. Sacchi, A. \& Salotti, S. (2016). A Comprehensive Analysis of Expend ure Decentralization and of the Composition of Local Public Spending. Regional Studies, 50(1), 93-109. doi: http://dx.doi.org/10.1080/00343404.2014.893387

72. Sanogo, T. (2019). Does fiscal decentralization enhance citizens' access to public services and reduce poverty? Evidence from Côte d'Ivoire municipalities in a conflict setting. World Development, 113, 204-221. doi: 10.1016/j.worlddev.2018.09.008.

75. Slavinskaite, N., Novotny, M. \& Gedvilaite, D. (2020). Evaluation of the fiscal decentralization: Case studies of European Union. Engineering Economics, 31(1), 84-92. doi: http://dx.doi.org/10.5755/j01.ee.31.1.23065

76. Sow, M. \& Razafimahefa, I. F. (2015). Fiscal Decentralization and the Efficiency of Public Service Delivery. Working Paper No. 15/59. Retrieved November 24, 2020, from https://www.imf.org/external/pubs/ft/wp/2015/wp1559.pdf.

77. Stavytskyy, A., Kharlamova, G., Giedraitis, V. \& Sengul, E.C. (2019). Gravity model analysis of globalization process in transition economies. Journal of International Studies, 12(2), 322-341. doi:10.14254/2071-8330.2019/12-2/21

78. Subires, M.D.L., Munoz, L.A., Galera, A.N. \& Bolivar, M.P.R. (2019). The Influence of SocioDemographic Factors on Financial Sustainability of Public Services: A Comparative Analysis in Regional Governments and Local Governments. Sustainability, 11(21), 6008. doi: $10.3390 /$ su11216008.

79. Svoboda, O. \& Applová, P. (2016). Determinants of Employment and GDP Resilience in the Context of an Economic Crisis: Evidence from EU Countries and Regions. Littera Scripta, 9(2), 140-155.

80. Šuleř, P. \& Machová V. (2020). Financial stability in Central European countries: Case of the Visegrad four. Proceedings of the 7th International Conference on Education and Social Sciences (INTCESS 2020). 1. vyd. Istanbul, Turkey: International Organization Center of Academic Research, 12181223.

81. Šumpíková, M. \& Ďurčeková, I. (2019). Transaction Costs, Outsourcing, and the Public Procurement Review Process in the Czech Republic and Slovakia. NISPAcee Journal of Public Administration and Policy, 12(2), 233-250. https://doi.org/10.2478/nispa-2019-0021.

82. Thalassinos, E., Cristea, M. \& Noja, G. G. (2019). Measuring active ageing within the European Union: implications on economic development. Equilibrium. Quarterly Journal of Economics and Economic Policy, 14(4), 591-609. https://doi.org/10.24136/eq.2019.028.

83. Virglerova, Z., Conte, F., Amoah, J. \& Massaro, M. R. (2020). The Perception of Legal Risk and Its Impact on the Business of SMEs. International Journal of Entrepreneurial Knowledge, 8(2), 1-13. https://doi.org/10.37335/ijek.v8i2.115

84. Vo, D. (2008). Fiscal decentralisation indices: a comparison of two approaches. Rivista di diritto finanæiario e scienza delle finanze, LXVII 3(1), 295-323.

85. Vokoun, M. (2017). Issues Inside the Field of Economics of Innovation: Definitions, Data Sources, Estimation Procedures and Comparability of Results. Littera Scripta, 10(2), 165-176.

86. Wierzbicka, W. (2020). Socio-economic potential of cities belonging to the Polish National Cittaslow Network. Oeconomia vocho, 11(1), 203-224. https://doi.org/10.24136/oc.2020.009. 
87. World Bank (2001). Decentralization \& Subnational Regional Economics. Service Delivery. Retrieved November 14 , fromhttp://www1.worldbank.org/publicsector/decentralization/service.htm.

88. Zeibote, Z., Volkova, T. \& Todorov, K. (2019). The impact of globalization on regional development and competitiveness: cases of selected regions. Insights into Regional Development, 1(1), 33-47. https://doi.org/10.9770/ird.2019.1.1(3)

\section{Brief description of Authors:}

Assoc. Prof. Martina Halaskova, Ph.D.

ORCID ID: https://orcid.org/0000-0002-6812-6158.

Email: martina.halaskova@vsb.cz

Assoc. Prof. Martina Halaskova, Ph.D. is an Associate Professor at the VŠB-Technical University of Ostrava, Faculty of Economics, where she teaches economic subjects that focus on economy of public administration and the public sector. In her scientific research activity, she deals with public economy, public services and selected areas from the public sector (sports, education, research and development) in the Czech Republic and European context. She cooperates with other universities in the Czech Republic and Slovakia. She is a member of the Czech Economic Society (CES) and a reviewer of selected domestic and foreign scientific journals.

\section{Assoc. Prof. Renata Halaskova, Ph.D.}

ORCID ID: https://orcid.org/0000-0002-2811-2210.

Email: renata.halaskova@osu.cz

Assoc. Prof. Renata Halaskova, Ph.D. is an Associate Professor at the University of Ostrava, where she teaches economics subjects that focus on services, public economics and administration and public services. In her scientific research activity, she deals with public economics, funding of public services, social policy and analysis of social services in the Czech Republic. Also, she cooperates with other universities in the Czech Republic. She is a member of the Czech Economic Society (CES) and a reviewer of selected domestic and foreign scientific journals.

\section{Prof. Beata Gavurova, Ph.D.}

ORCID ID: https://orcid.org/0000-0002-0606-879X.

Email: beata.gavurova@tuke.sk

Prof. Beata Gavurova, Ph.D. is a Professor at the Technical University of Košice, Faculty of Mining, Ecology, Process Control and Geotechnologies, Institute of Earth Resources. She is an expert in finance, financial analysis and financial risk management. She focuses in her research work on issues of measurement and performance management in various sectors, process management and process optimization, strategic and performance benchmarking. Her dominant research area is the development and testing in the management and performance measurement, the evaluation of methodologies and the preparation of an application platform for innovative management and performance measurement with the support of ICT.

\section{Assoc. Prof. Matus Kubak, Ph.D.}

ORCID ID: https://orcid.org/0000-0003-1438-479X.

Email: matus.kubak@tuke.sk

Assoc. Prof. Matus Kubak, Ph.D. focuses his scientific and research activities on the use of parametric and non-parametric quantitative methods on economic issues and data mining. His research interest is in experimental economics, health economics, public procurement and agent based modelling. 